\title{
KOMUNIKASI SOSIAL DALAM MENSOSIALISASIKAN PENETAPAN KEBIJAKAN GUBERNUR BALI TENTANG PEMBATASAN TIMBULAN SAMPAH PLASTIK SEKALI PAKAI
}

\author{
Niluh Wiwik Eka Putri \\ STAHN Mpu Kuturan Singaraja \\ wiwikekaputri@gmail.com
}

\begin{abstract}
Bali is a tourist destination so cleanliness and the beauty of tourist areas are an absolute requirement in the world of tourism. The provincial government of Bali issued a governor regulation number 97 of 2018 concerning restrictions on the generation of disposable plastic waste. Handling waste problems is not only the responsibility of one party, but must involve all elements, namely; community, government and private sector. The existence of community-based waste management groups, as well as other stakeholders is expected to be the driver of achieving TrashFree Indonesia in 2020, especially Bali. This study aims to determine social communication in socializing the policy of limiting the generation of plastic waste in Bali. This study uses a qualitative approach with action research methods. The results of the study show that social communication about the policy of limiting the generation of disposable plastic waste issued by the Governor of Bali has succeeded in increasing public awareness in reducing the use of plastic. In carrying out social communication, the Governor of Bali conducts social contacts in primary (direct) or secondary (mass media). With the existence of social contacts, social change occurs in accordance with what is expected by the provincial government of Bali.
\end{abstract}

Keywords: Social Communication, Socialization, Governor of Bali Policy

\begin{abstract}
Abstrak
Bali merupakan tujuan daerah wisata maka kebersihan serta keasrian syarat mutlak dalam pariwisata. Pemerintah provinsi Bali mengeluarkan kebijakan peraturan gubernur nomor 97 tahun 2018 tentang pembatasan timbulan sampah plastik sekali pakai. Penanganan masalah sampah harus melibatkan semua elemen yaitu; masyarakat, pemerintah maupun swasta. Keberadaan kelompok-kelompok pengelolaan sampah berbasis masyarakat, maupun stakeholder lainnya diharapkan menjadi pendorong tercapainya Indonesia Bebas Sampah di tahun 2020 khususnya Bali. Penelitian ini bertujuan untuk mengetahui komunikasi sosial dalam mensosialisasikan penetapan kebijakan pembatasan timbulan sampah plastik di Bali. Penelitian ini menggunakan pendekatan kualitatif dengan metode action research. Adapun hasil penelitian menunjukkan bahwa Komunikasi sosial tentang kebijakan pembatasan timbulan sampah plastik sekali pakai yang dikeluarkan oleh Gubernur Bali telah berhasil meningkatkan kesadaran masyarakat dalam mengurangi pemakaian plastik. Dalam melaksanakan komunikasi sosial, Gubernur Bali melakukan kontak sosial secara primer (langsung) ataupun sekunder (media massa). Dengan adanya kontak sosial, maka terjadi perubahan sosial sesuai dengan apa yang diharapkan oleh pemerintah provinsi Bali.
\end{abstract}

Kata Kunci: Komunikasi Sosial, Sosialisasi, Kebijakan Gubernur Bali 


\section{PENDAHULUAN}

Sampah plastik memadati bibir pantai di Kawasan pesisir. Saat ini volume rata-rata timbulan sampah di Bali mencapai 10.849,10 m3 per hari. Pemerintah provinsi Bali mengeluarkan kebijakan peraturan gubernur nomor 97 tahun 2018 tentang pembatasan timbulan sampah plastik sekali pakai. Aturan ini secara ketat melarang penggunaan kantong plastik sekali pakai, styrofoam (polisterina), dan sedotan plastik oleh produsen, distributor, dan pelaku usaha di seluruh Bali.

Pergub ini antara lain bertujuan untuk menjaga kesucian, keharmonisan, keselarasan dan keseimbangan lingkungan hidup, mencegah pencemaran dan kerusakan lingkungan akibat penggunaan plastik sekali pakai, dan menjaga ekosistem, menjamin kesehatan masyarakat. Juga menjamin generasi masa depan untuk tidak tergantung pada penggunaan plastik sekali pakai.

Mengingat Bali merupakan tujuan daerah wisata maka kebersihan serta keasrian kawasan wisata, menjadi syarat mutlak dalam dunia pariwisata. Adanya Perwali maupun Pergub tentang pengurangan sampah plastik merupakan satu step dari solusi pengurangan sampah yang ada di Bali. Hasil penelitian yang dilakukan oleh Hendrawan pada tahun 2016 bahwa jumlah sampah plastik di Pantai Kuta sebanyak 0,5 sampai 1,5 pcs per meter persegi.

Sementara dari peta sebaran sampah, terlihat hampir rata di seluruh pesisir. Makin besar bulatan, maka volumenya makin besar. Termasuk pantai-pantai terkenal di Bali Selatan seperti
Serangan, Kedonganan, Kuta, Legian, kemudian Bali Utara, dan Bali Barat. Ini adalah bagian dari sejumlah aspek yang diteliti tentang sampah laut. Penelitian sebelumnya adalah pergerakan sampah dan jenis sampah yang mendarat di pantai-pantai berhadapan dengan Selat Bali sejak 2014. Kemudian jenis sampah yang terdampar di Pantai Kuta, karena paling banyak terekspos oleh turis.

Menurut UU No. 18 Tahun 2008 menyatakan bahwa Sampah adalah sisa kegiatan sehari-hari manusia dan atau proses alam yang berbentuk padat. Sampah spesifik adalah sampah yang karena sifat, konsentrasi, dan atau volumenya memerlukan pengelolaan khusus. Sumber sampah adalah asal timbulan sampah. Penghasil sampah adalah setiap orang dan atau akibat proses alam yang menghasilkan timbulan sampah. Pengelolaan sampah adalah kegiatan yang sistematis, menyeluruh, dan berkesinambungan yang meliputi pengurangan dan penanganan sampah. Tempat penampungan sementara adalah tempat sebelum sampah diangkut ke tempat pendauran ulang, pengolahan, dan atau tempat pengolahan sampah terpadu. Tempat pengolahan sampah terpadu adalah tempat dilaksanakannya kegiatan pengumpulan, pemilahan, penggunaan ulang, pendauran ulang, pengolahan, dan pemrosesan akhir sampah.

Peraturan Daerah yang mengatur ketertiban umum di wilayah Kota Denpasar adalah Peraturan Daerah Nomor 3 Tahun 2015 tentang Pengelolaan Sampah. Dalam hal ini yang menjadi perhatian adalah kebersihan lingkungan dalam wilayah 
Kota Denpasar khusunya mengenai penanganan sampah yang dihasilkan oleh masyarakat Denpasar sendiri yang semakin hari semakin bertambah.

Penanganan masalah sampah tidak hanya menjadi tanggung jawab satu pihak, tetapi harus melibatkan semua elemen yaitu; masyarakat, pemerintah maupun swasta. Keberadaan kelompokkelompok pengelolaan sampah berbasis masyarakat, maupun stakeholder lainnya diharapkan menjadi pendorong tercapainya Indonesia Bebas Sampah di tahun 2020. Prinsip utama mengelola sampah yang benar adalah mencegah timbulan sampah, mengguna ulang sampah, dan mendaur ulang sampah, merupakan prinsip 3R yaitu reduce, reuse, dan recycle (http://www.menlh.go.id.).

Komunikasi sosial menjadi poin penting untuk diteliti karena setiap aktivitas yang dilakukan oleh beberapa dinas dan lembaga pemerintahan, Yayasan dan Lembaga Swadaya Masyarakat (LSM), serta masyarakat setempat adalah proses komunikasi sosial untuk mendorong munculnya kebijakan publik mengenai pembatasan timbulan sampah plastik sekali pakai.

Komunikasi sosial merupakan suatu proses interaksi antarpersonal atau antarlembaga melalui penyampaian pesan tertentu untuk menciptakan integrasi atau adaptasi sosial. Komunikasi sosial merupakan sebuah proses interaksi di mana seseorang atau lembaga menyampaikan pesan kepada pihak lain supaya pihak lain dapat menangkap maksud yang dikehendaki oleh komunikator. Definisi lain menyebutkan bahwa komunikasi merupakan sebuah proses sosial dalam masyarakat. Proses sosial ini diartikan sebagai pengaruh timbal balik antara berbagai individu, masyarakat, maupun organisasi dalam kehidupan bersama. Komunikasi sosial juga dapat diartikan menjadi suatu aktivitas komunikasi untuk tujuan integrasi sosial (Vera \& Wihardi, 2012).

Menurut Cangara (2007:23) unsurunsur komunikasi antara lain; 1. Sumber. Sumber peristiwa komunikasi akan melibatkan sumber sebagai pembuat atau pengirim informasi. Sumber bisa terdiri dari satu orang, tetapi bisa juga dalam bentuk kelompok, partai, organisasi, atau lembaga.; 2. Pesan. Pesan adalah sesuatu yang disampaikan pengirim kepada penerima. Pesan dapat disampaikan dengan cara tatap muka atau melalui media komunikasi yang isinya dapat berupa ilmu pengetahuan, hiburan, informasi, nasehat atau propaganda.; 3. Media. Media yang dimaksud adalah alat yang digunakan untuk memindahkan pesan dari sumber kepada penerima. Dalam komunikasi antarpribadi panca indera dan berbagai saluran komunikasi seperti telepon, telegram digolongkan sabagai komunikasi.; 4. Penerima. Penerima adalah pihak yang menjadi sasaran pesan yang dikirim oleh sumber. Penerima bisa terdiri dari satu orang atau lebih, bisa dalam bentuk kelompok, partai atau negara.; 5. Pengaruh. Pengaruh atau efek adalah perbedaan atau apa yang dipikirkan, dirasakan dan dilakukan oleh penerima sebelum dan sesudah penerima pesan.; 6. Tanggapan balik. Umpan balik adalah salah satu bentuk dari pada pegaruh yang berasal dari penerima, tetapi sebenarnya umpan balik bisa juga berasal dari unsur lain seperti pesan dan 
media, meski pesan belum sampai pada penerima.; 7. Lingkungan. Lingkungan atau situasi adalah faktor-faktor tertentu yang dapat mempengaruhi jalannya komunikasi. Faktor ini dapat digolongkan dalam empat macam yakni lingkungan fisik, lingkungan sosial budaya, lingkungan psikologis dan lingkungan dimensi waktu.

Woll sebagaimana dikutip Tangkilisan (2003:2) menyebutkan bahwa kebijakan publik adalah sejumlah aktivitas pemerintah untuk memecahkan masalah di tengah masyarakat, baik secara langsung maupun melalui berbagai lembaga yang mempengaruhi kehidupan masyarakat.

James E. Anderson sebagaimana dikutip Islamy (2009: 17) mengungkapkan bahwa

kebijakan adalah " a purposive course of action followed by an actor or set of actors in dealing with a problem or matter of concern" (Serangkaian tindakan yang mempunyai tujuan tertentu yang diikuti dan dilaksanakan oleh seorang pelaku atau sekelompok pelaku guna memecahkan suatu masalah tertentu).

Dari definisi para ahli di atas maka dapat disimpulkan bahwa kebijakan public adalah: "Serangkaian keputusan kebijaksanan yang diambil seorang atau sekelompok orang untuk mewujudkan tujuan-tujuan tertentu di dalam masyarakat"

Ramdhani \& Ramdhani (2017:3) menunjukkan bahwa kebijakan publik adalah serangkaian keputusan pemerintah yang terukur, mengarah pada tujuan tertentu, menyangkut kepentingan publik, dan melibatkan para pihak yang berkepentingan dalam bidang-bidang tertentu. Sedangkan pelaksanaan kebijakan merupakan tahapan aktivitas, kegiatan, program dalam melaksanakan keputusan kebijakan yang dilakukan oleh individua tau pejabat, kelompok pemerintah, masyarakat, dan atau swasta dalam rangka pencapaian tujuan yang telah ditetapkan untuk memengaruhi hasil akhir suatu kebijakan. Kebijakan publik dalam penelitian ini merujuk pada peraturan daerah mengenai penetapan kebijakan pembatasan timbulan sampah plastik sekali pakai.

Penelitian ini bermaksud untuk menggali tentang komunikasi sosial kebijakan pembatasan timbulan sampah plastik sekali pakai yang dikeluarkan oleh Gubernur Bali, sehingga mampu diaplikasikan oleh seluruh lapisan masyarakat, khususnya masyarakat Bali.

\section{METODE PENELITIAN}

Dalam lingkup penelitian kebijakan memang telah dikenal lama tentang model action research. Dilihat dari konteks praxis, model action research merupakan model penelitian yang sekaligus berpraktik dan berteori, atau menggabungkan teori sekaligus melaksanakan dalam praktik. Dalam Bahasa Indonesia Action Research diterjemahkan dengan "penelitian tindakan", namun ada juga yang menyebut dengan "kaji tindak".

Noeng Muhadjir (2000) membedakan dengan Research and Development (R\&D), yang diadakan penelitian terlebih dahulu baru kemudian dirancangkan pengembangannya. Penelitian ini sebagian mulai dengan kerangka teori, dilanjutkan dengan pengumpulan data, 
analisis, dan diakhiri dengan kesimpulan. Pengembangan dilakukan dengan implementasinya, mungkin juga dengan penelitian lanjutannya. Sedang action research melakukan secara sekaligus antara berteori dan berpraktik yang rotasi kegiatannya sebagaimana terjelaskan diatas (M-R-D-E).

Penelitian ini didesain dengan pendekatan action research, yaitu suatu kerangka penelitian pemecahan masalah. Penelitian action research ini mendorong peneliti untuk mendeskripsikan, menginterpretasikan, dan menjelaskan suatu situasi sosial pada waktu yang bersamaan dengan melakukan perubahan atau intervensi dengan tujuan perbaikan atau partisipasi.

Sugiyono (2010:295) mengatakan bahwa semua penelitian bersifat ilmiah. Oleh karena itu semua peneliti harus berbekal teori. Dalam penelitian kualitatif, permasalahan yang dibawa masih bersifat sementara, sehingga teori yang digunakan dalam penyusunan proposal penelitian kualitatif juga masih bersifat sementara dan dapat berkembang setelah peneliti memasuki lapangan atau konteks sosial. Penelitian kuantitatif bersifat menguji hipotesis atau teori, sedangkan penelitian kualitatif bersifat menemukan teori.

\section{HASIL DAN PEMBAHASAN Kontak Sosial}

Menurut Soeryono Soekanto (2002:65), kontak sosial berasal dari bahasa latin con atau cum (bersamasama) dan tango (menyentuh), jadi artinya secara harfiah adalah bersamasama menyentuh. Secara fisik, kontak sosial baru terjadi apabila adanya hubungan fisik, sebagai gejala sosial hal itu bukan semata-mata hubungan badaniah, karena hubungan sosial terjadi tidak saja secara menyentuh seseorang, namun orang dapat berhubungan dengan orang lain tanpa harus menyentuhnya. Misalnya kontak sosial sudah terjadi ketika seseorang berbicara dengan orang lain, bahkan kontak sosial juga dapat dilakukan dengan menggunakan teknologi, seperti melalui telepon, telegrap, radio, surat, televisi, internet, dan sebagainya.

Kontak sosial dapat berlangsung dalam lima bentuk yaitu:

a. Dalam bentuk proses sosialisasi yang berlangsung antara pribadi orang per orang. Proses sosialisasi ini memungkinkan seseorang mempelajari normanorma yang terjadi di masyarakatnya. Berger dan Luckmann (Bugin, 2001:14), mengatakan proses ini terjadi melalui proses objektivitas, yaitu interaksi sosial yang terjadi dalam dunia intersubjektif yang dilembagakan atau mengalami proses institusionalisasi.

b. Antara orang per orang dengan suatu kelompok masyarakat atau sebaliknya.

c. Antara kelompok masyarakat dengan kelompok masyarakat lainnya dalam sebuah komunitas.

d. Antara orang per orang dengan masyarakat global di dunia internasional.

e. Antara orang per orang, kelompok, masyarakat dan dunia global, di mana kontak sosial terjadi secara simultan diantara mereka.

Kehidupan seseorang saat ini telah masuk pada dunia yang serba pilihan, 
seseorang dapat memilih ia hidup dalam kelompok atau ia hidup dalam sebuah masyarakat, bahkan ia boleh hidup dalam dunia yang serba global. Seseorang juga dapat memilih hidup dalam masyarakat lokal atau memilih hidup dalam masyarakat global, bahkan boleh hidup di dalam kedua kehidupan itu yaitu majemuk dan rumit. Kerumitan ini pula dipacu dengan perkembangan teknologi informasi, sehingga dimanapun ia berada, ia dapat melakukan kontak sosial dengan siapa saja dan dimana saja yang ia inginkan. Kontak sosial bukan saja menjadi kebutuhan namun juga menjadi pilihan dengan siapa ia melakukannya.

Secara konseptual kontak sosial dapat dibedakan antara kontak sosial primer dan kontak sosial sekunder. Kontak sosial primer yaitu kontak sosial yang terjadi secara langsung antara seseorang dengan orang atau kelompok masyarakat lainnya secara tatap muka. Sedangkan kontak sosial sekunder terjadi melalui perantara yang sifatnya manusiawi maupun dengan teknologi. Ketika masyarakat saat ini telah berkembang dengan tingkat kemajuan teknologi informasi semacam ini, maka kontak-kontak sosial primer dan sekunder semakin sulit dibedakan satu dengan lainnya. Seperti kontak telepon yang menggunakan teknologi teleconfrensce dimana kontak terjadi antara orang per orang (orang dengan kelompok dan sebagainya), secara tatap muka dan saling dapat menyapa namun dari yang terjadi dengan internet juga dapat langsung menyapa dan saling tatap muka walaupun tempat mereka berjauhan. Semua ini menjadi fenomena yang mengacaukan konsep- konsep lama tentang kontak sosial tersebut (Bungin, 2006:55).

Gubernur Bali melakukan kontak sosial dengan seluruh lapisan masyarakat. Hal tersebut dilihat dari berita di buletindewata.com.

"Gubernur Bali Wayan Koster mengajak semua lapisan masyarakat, pelaku usaha, instansi pemerintah serta pihak lainnya untuk ikut mengimplementasikan

Peraturan Gubernur (Pergub) 97 Tahun 2018 tentang Pembatasan Timbulan Sampah Plastik Sekali Pakai, agar alam Bali beserta isinya tetap sejuk, indah dan harmonis. Demikian tegaskan Wayan Koster saat Deklarasi Bali Bersih Sampah Plastik dengan Gerakan Kedas Sampah Plastik, di kawasan Pura Agung Besakih, Karangasem, Sabtu (2/2).

Wayan Koster menjelaskan Peraturan Gubernur Nomor 97 Tahun $2018 \quad$ tentang Pembatasan Timbulan Sampah Plastik Sekali Pakai, juga bertujuan untuk menjaga kesucian, keharmonisan, keselarasan dan keseimbangan lingkungan hidup serta membangun partisipasi masyarakat untuk berperan serta dalam perlindungan lingkungan hidup. "Saya harap kegiatan seperti ini diikuti seluruh masyarakat Bali. Tidak hanya dilaksanakan di Besakih saja, namun juga dilaksanakan diseluruh Bali. Untuk itu, saya mengajak 
komponen masyarakat seluruh Bali agar ikut secara aktif dan melaksanakan Pergub 97 dengan cara membersihkan lingkungan dari sampah plastik. Pemerintah Kabupaten/Kota harus membuat aturan serupa, serta di tingkat desa saya harapkan ada semacam pararem, sehingga gerakan ini bisa berkelanjutan dan dilaksanakan dengan sebaik mungkin," ujar Wayan Koster.

Gubernur Koster yang didampingi Ny. Putri Suastini Koster, Wagub Bali Cok Ace beserta Ny. Putri Haryani Sukawati, berharap pergub ini mendapat dukungan dari semua pihak agar pelaksanaannya tetap berlanjut. Kegiatan bersihbersih sampah plastik juga sesuai dengan visi Nangun Sat Kerthi Loka Bali, yakni menjaga kesucian alam Bali berserta isinya untuk mewujudkan kehidupan krama Bali yang sejahtera, bahagia sekala dan niskala. "Terima kasih atas gerakan bersih sampah plastik ini. Kegiatan ini adalah bagian dari pada cara menyukseskan pergub yang bertujuan agar Bali bebas dari sampah plastik sekali pakai. Saya juga mengucapkan terimakasih atas respon positif dari masyarakat Bali terkait pergub ini," imbuhnya. Kegiatan kedas sampah plastik ini dipelopori Perhimpunan
Pemuda Hindu (Peradah) Indonesia Provinsi Bali, Kesatuan Mahasiswa Hindu Dharma Indonesia (KMHDI) Provinsi Bali, bekerjasama dengan Pemerintah Provinsi Bali, Kepolisian Daerah Bali, Kodam IX/Udayana, Perguruan Tinggi se-Bali, Pemerintah Kabupaten/Kota se-Bali, siswa SMP/SMA, komunitas serta masyarakat. Kegiatan diikuti 10 ribu perserta tersebut sekaligus menjadi salah satu wujud nyata implementasi pergub 97 tahun 2018, untuk menyongsong Karya Agung Panca Wali Krama, sehingga selama mapun sesudah pelaksanaan karya pura Besakih tetap bisa bersih dari sampah plastik. Para pemedek pun yang akan tangkil bersembahyang ke Pura Besakih diimbau untuk tidak membawa dan menggunakan plastik".

Dari kutipan berita diatas dapat disimpulkan bahwa telah terjadi kontak sosial primer dimana Gubernur Bali secara langsung bertatap muka dengan seluruh lapisan masyarakat. Hal ini menunjukkan kesungguhan dalam mengimplementasikan pergub tentang pembatasan timbulan sampah plastik sekali pakai. Adapun kontak sosial terjadi secara langsung antara seseorang dengan orang atau kelompok masyarakat lainnya secara tatap muka.

Selain itu, Gubernur Bali juga melakukan kontak sosial secara sekunder melalui media massa. Seperti 
kegiatan Press Conference yang dilakukan di Gedung Wiswa Sabha yang dimuat oleh bali.tribunnews.com.

"Gubernur Bali, Wayan Koster menyebutkan ada 3 bahan yang terbuat dari/atau mengandung bahan dasar plastik yang dilarang penggunaannya dalam Peraturan Gubernur No. 97 Tahun 2018, yang akan dilaksanakan mulai 1 Januari 2019 saat menggelar konferensi pers di Gedung Wiswa Sabha, Kantor Gubernur Bali, Kota Denpasar, Bali, Senin (24/12/2018). Dalam Peraturan Gubernur 3 bahan yang dilarang yaitu kantong plastik, polysterina (styrofoam), dan sedotan plastik. "Yang dijangkau ini adalah produsen, distributor, pemasok, pelaku usaha termasuk perorangan. Jadi yang dijangkau itu banyak, yang dilarang. Dan harus menyiapkan bahan penggantinya," jelas Gubernur Koster, Senin (24/12/2018).

Instruksi dan surat edaran terkait Peraturan Gubernur tentang pembatasan sampah plastik sekali pakai akan diinstruksikan kepada semua pihak yang terkait. "Nanti akan diberikan instruksi, sosialisasi, advokasi, pendampingan terkait Peraturan Gubernur tentang pembatasan sampah plastik sekali pakai kepada semua pihak terkait," imbuhnya. Sebagai bentuk apresiasi, Pemerintah Provinsi Bali akan memberikan penghargaan bagi Instansi pemerintahan, BUMD, lembaga swasta, lembaga keagamaan, lembaga sosial, desa adat/desa pakraman, masyarakat dan perorangan yang taat melaksanakan Peraturan Gubernur. Sebaliknya, Pemerintah Provinsi Bali akan memberikan sanksi bagi pihakpihak yang tidak mematuhi ketentuan dalam Peraturan Gubernur. "Sanksi hukuman itu tidak ada, tetapi sanksi administratif nanti kalau dia tidak tertib izin usahanya tidak diperpanjang," tutupnya".

Melalui konferensi pers yang digelar di Gedung Wiswa Sabha, gubernur bali koster telah melakukan kontak sosial secara sekunder. Hal ini terlihat dari kegiatan yang dilakukan dengan masyarakat yang diliput oleh media massa. Sehingga masyarakat di seluruh Indonesia khususnya Bali dapat mengetahui lebih mendalam terkait pergub tentang pembatasan timbulan sampah plastik sekali pakai.

\section{Perubahan Sosial}

Perubahan sosial adalah proses sosial yang dialami oleh anggota masyarakat serta semua unsur-unsur budaya dan sistem-sistem sosial, dimana semua tingkat kehidupan masyarakat secara sukarela atau dipengaruhi oleh unsur-unsur eksternal meninggalkan pola-pola kehidupan, budaya, dan sistem sosial lama kemudian menyesuaikan diri atau menggunakan pola-pola kehidupan, budaya, dan sistem sosial yang baru.

Perubahan sosial terjadi ketika ada kesediaan anggota masyarakat untuk meninggalkan unsur-unsur budaya dan sistem sosial lama dan mulai beralih 
menggunakan unsur-unsur budaya dan sistem sosial yang baru. Perubahan sosial dipandang sebagai konsep yang serba mencakup seluruh kehidupan masyarakat baik pada tingkat individual, kelompok, masyarakat, negara, dan dunia yang mengalami perubahan.

Hal-hal penting dalam perubahan sosial menyangkut aspek-aspek sebagai berikut yaitu; perubahan pola pikir masyarakat, peubahan perilaku masyarakat, perubahan budaya materi. Pertama, perubahan pola pikir dan sikap masyarakat menyangkut persoalan sikap masyarakat terhadap berbagai persoalan sosial dan budaya disekitarnya yang berakibat terhadap pemetaraan pola-pola pikir baru yang dianut oleh masyarakat sebagai sebuah sikap yang modern. Contohnya, sikap terhadap pekerjaan bahwa konsep dan pola pikir lama tentang pekerjaan adalah sektor formal (menjadi pegawai negeri), sehingga konsep pekerjaan dibagi menjadi dua yaitu sektor formal dan informal. Saat ini terjadi perubahan terhadap konsep kerja lama dimana pekerjaan konsep tidak sebagai sector formal (menjadi pegawai negeri), akan tetapi dikonsepkan sebagai sektor yang menghasilkan pendapatan maksimal. Dengan demikian, maka bekerja tidak saja disektor formal, akan tetapi dimana saja yang penting menghasilkan uang yang maksimal, dengan demikian konsep kerja menjadi sektor formal, yaitu bekerja dipemerintahan sektor swasta yaitu bekerja diperusahaan swasta besar, sektor informal yaitu bekerja di sektor informal seperti wiraswasta kecil, kaki lima, LSM dan sebagainya, serta sektor lepas yaitu bekerja sebagai secara kontrakkan di berbagai kegiatan, proyek dan sebagainya. Kedua perubahan perilaku masyarakat menyangkut persoalan perubahan sistem-sistem sosial, dimana masyarakat meninggalkan sistem sosial lama, dan menjalankan sistem sosial baru, seperti perubahan perilaku pengukuran kinerja suatu Lembaga atau instansi. Apabila pada sistem lama, ukuran-ukuran kinerja hanya dilihat dari aspek output dan proses tanpa harus mengukur sampai sampai dimana output dan proses itu dicapai maka pada sistem sosial yang baru sebuah Lembaga atau instansi diukur sampai pada tingkat kinerja output dan proses itu yaitu dengan menggunakan standar sertifikasi seperti BAN-PT pada perguruan tinggi dan sertifikasi ISO pada Lembaga-lembaga umum termasuk perguruan tinggi. Ketiga, perubahan budaya materi menyangkut perubahan artefak budaya yang digunakan oleh masyarakat, seperti model pakaian, karya fotografi, karya film, teknologi, dan sebagainya yang terus berubah dari waktu ke waktu menyesuaikan kebutuhan masyarakat.

SKEMA 1

\section{TAHAPAN TRANSISI SOSIOLOGIS}

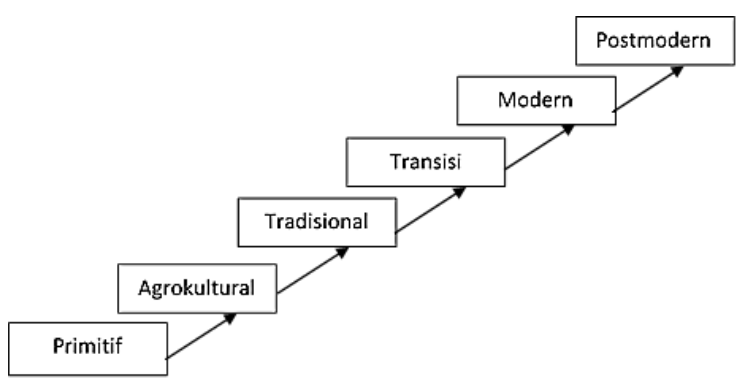

Mayarakat memulai kehidupan mereka pada suatu fase yang disebut primitif dimana manusia hidup secara terisolir dan berpindah-pindah disesuaikan dengan lingkungan alam 
dan sumber makanan yang tersedia. Manusia saat ini hidup dalam kelompok-kelompok kecil (band) dan terpisah dengan kelompok manusia lainnya.

Fase berikutnya adalah fase agrokultural, ketika lingkungan alam mulai tidak lagi mampu memberi dukungan terhadap manusia, termasuk juga karena populasi manusia mulai banyak, maka pilihan budayanya adalah bercocok tanam di suatu tempat dan memanen hasil pertanian itu serta berburu untuk memenuhi kebutuhan masyarakat. Pada fase ini budaya berpindah-pindah masih tetap digunakan walaupun pada skala waktu yang relative lebih lama.

Fase tradisional dijalani oleh masyarakat dengan hidup secara menetap disuatu tempat yang dianggap strategis untuk penyediaan berbagai kebutuhan hidup masyarakat, seperti di pinggir sungai, di pantai, di lereng bukit, di dataran tinggi, di daratan rendah yang datar, dan sebagainya. Pada fase ini kita mulai mengenal kata 'desa' dimana beberapa band (kelompok kecil masyarakat) memilih menetap dan saling berinteraksi satu dan lainnya sehingga menjadi kelompok besar dan menjadi komunitas desa, mengembangkan budaya dan tradisi internal serta membina hubungan dengan masyarakat di sekitarnya.

Pada fase transisi, kehidupan desa sudah sangat maju, isolasi kehidupan hampir tidak ditemukan lagi dalam skala luas, transportasi sudah lancer walaupun untuk masyarakat desa tertentu masih menjadi masalah. Penggunaan media informasi sudah hamper merata. Namun secara geografis, masyarakat transisi berada di pinggiran kota serta hidup mereka masih secara tradisional, termasuk pola piker dan sistem sosial lama masih silih berganti digunakan dan mengalami penyesuaian dengan hal-hal yang baru dan inovatif. Dengan demikian, maka umumnya masyarakat transisi bersifat mendua atau ambigu terhadap sikap, pandangan, dan perilaku mereka seharihari. Pola pikir masyarakat masih tradisional dan mereka memelihara kekerabatan namun perilaku masyarakat sudah terlihat individualis. Sesuatu yang masih dominan dalam kehidupan masyarakat ini adalah proses asimilasi budaya dan sosial yang belum tuntas dan terlihat masih canggung di semua level masyarakat.

Fase modern ditandai dengan peningkatan kualitas perubahan sosial yang lebih jelas meninggalkan fase transisi. Kehidupan masyarakat sudah kosmopolitan dengan kehidupan individual yang sangat menonjol, profesionalisme di segala bidang dan penghargaan terhadap profesi menjadi kunci hubungan-hubungan sosial diantara elemen masyarakat. Di sisi lain sekularisme menjadi sangat dominan dalam sistem religi dan kontrol sosial masyarakat serta sistem kekerabatan mulai diabaikan. Anggota masyarakat hidup dalam sistem yang sudah mekanik, kaku, dan hubunganhubungan sosial ditentukan berdasarkan pada kepentingan masingmasing elemen masyarakat. Masyarakat modern umumnya berpendidikan relatif lebih tinggi dari masyarakat transisi sehingga memiliki tingkat pengetahuan yang lebih luas dan pola pikir yang lebih rasional dari semua tahapan kehidupan masyarakat sebelumnya, 
walaupun kadang Pendidikan formal saja tidak cukup untuk mengantarkan masyarakat pada tingkat pengetahuan dan pola pikir semacam itu. Secara demografis, masyarakat modern menempati lingkungan perkotaan yang cenderung gersang dan jauh dari situasi yang sejak dan rindang, ditambah lagi karena kehidupan mereka yang serba mekanik sepanjang minggu sehingga masyarakat kota memiliki kepedulian yang tinggi terhadap kebutuhan rekreasi di akhir minggu untuk rileks dan melepaskan kepenatan.

Fase postmodern adalah sebuah fase perkembangan masyarakat yang pertama-tama dikenal di Amerika Serikat pada akhir tahun 1980-an. Di Indonesia ciri masyarakat postmodern sesungguhnya adalah masyakarat modern yang secara finansial, pengetahuan, relasi, dan semua prasyarat sebagai masyarakat modern sudah dilampauinya. Walaupun terkadang ada satu dua masyarakat modern yang terlihat memiliki ciri postmodern walaupun belum memiliki kemampuan tersebut, namun hal itu bersifat temporer dan meniru-niru kelompok lain yang lebih mapan. Jadi masyarakat postmodern adalah masyarakat modern dengan kelebihankelebihan tertentu dimana kelebihankelebihan itu menciptakan pola sikap dan perilaku serta pandanganpandangan mereka terhadap diri dan lingkungan sosial yang berbeda dengan masyarakat modern atau masyarakat sebelum itu. Sifat-sifat yang menonjol dari amsyarakat postmodern adalah:

a) Memiliki pola hidup nomaden, artinya kehidupan mereka yang terus bergerak dari satu tempat ke tempat lain menyebabkan orang sulit menemukan mereka secara ajeg termasuk dapat mendeteksi dimana tempat tinggal menetapnya. Hal ini di sebabkan karena kesibukan mereka dengan berbagai usaha dan bisnis, akhirnya mereka bisa saja memiliki rumah dimanamana di dunia.

b) Secara sosiologis mereka berada pada titik nadir, antara struktur dan agen, yaitu pada kondisi tertentu orang postmodern patuh pada strukturnya, namun pada sisi lain ia mengekspresikan dirinya sebagai agen yang mereproduksi struktur atau paling tidak agen yang terlepas dari strukturnya. Berdasarkan hal tersebut, maka berdasarkan pengamatan "orang luar" sesungguhnya pribadi postmodern adalah pribadi yang secara permanen ambivalensia atau mereka yang ambigu dalam pilihanpilihan hidup mereka. Namun sesungguhnya pada pribadi-pribadi postmodern hal tersebut adalah pilihanpilihan hidup yang demokratis dan ekspresi dari kebebasan pribadi orangorang cosmopolitan.

c) Manusia postmodern lebih suka menghargai privasi, dan kegemaran mereka melebihi apa yang mereka anggap berharga dalam hidup 
mereka, dengan demikian kegemaran spesifik mereka menjadi aneh-aneh dan unik.

d) Kehidupan pribadi yang bebas menyebabkan orangorang postmodern menjadi sangat sekuler, memiliki pemahaman nilai-nilai sosial yang subjektif dan liberal sehingga cenderung terlihat sangat mobile pada seluruh komunitas masyarakat dan agama serta berbagai pandangan politik sekalipun.

e) Pemahaman orang postmodern yang bebas pula menyebabkan mereka cenderung melakukan gerakan back to nature, back to village, back to tradisional atau bahkan back to religi, namun karena pemahaman mereka yang luas tentang persoalan kehidupan, maka "gerakan kembali" itu memiliki perspektif yang berbeda dengan orang lain yang selama ini sudah dan sedang ada di wilayah tersebut.

Perubahan sosial yang terjadi sejak di keluarkannya kebijakan peraturan gubernur nomor 97 tahun 2018 tentang pembatasan timbulan sampah plastik sekali pakai antara lain yaitu:

Munculnya gerakan "kedas sampah plastik" yang digagas oleh Mahasiswa dan Pemuda Hindu di Bali yang tergabung dalam organisasi DPP Peradah Bali dan PD KMHDI Bali. Hal tersebut dapat dilihat dari surat panitia gerakan sampah plastik Nomor: 010/B/PAN/GKSP/I/2019. Kegiatan kedas sampah plastik diadakan dibeberapa titik seperti di pantai Biaslantang Kaler, Desa Purwakerthi, Kecamatan Abang, Karangasem dan di Pura Sad Kahyangan Lempuyang, Desa Purwayu, Kecamatan Abang. Kemudian di Kawasan Pura Agung Besakih, Kecamatan Rendang, Kabupaten Karangasem.

Hal ini sejalan dengan kebijakan dari Walikota Denpasar yang sebelumnya telah mengeluarkan perwali no 36 tahun 2018 tentang diet plastik. Dalam mendukung gerakan kedas sampah plastik walikota Denpasar melakukan sosialisasi, beberapa diantaranya seperti di pasar Agung, pasar Peninjoan, pasar Waringin Sari Angabaya Penatih, pasar Nyanggelan Panjer. Untuk mengurangi sampah plastik walikota Denpasar memberikan 600 Tas Belanja secara gratis. Tujuannya untuk memberikan edukasi kepada masyarakat agar ikut peduli mengurangi sampah palstik dengan menggunakan bahan-bahan yang ramah lingkungan. Selain itu, penggunaan tas belanja yang dapat dipakai secara berulang-ulang tentu dapat membantu meminimalisir penggunaan tas belanja sekali pakai.

Toko Modern yang sudah berperan dalam mendukung Pergub Bali antara lain Tiara Dewata, Indomaret dan Alfamart.

"Disamping menyasar Toko Modern dikawasan tersebut, DLHK Denpasar langsung menuju ke Pusat Perbelanjaan Tiara Dewata. Tim langsung menuju pusat penjualan kebutuhan pokok. Dalam peninjauan tersebut tampak masyarakat yang berbelanja tidak diberikan kantong plastik, namun pada kasir menawarkan 
konsumen tas ramah lingkungan berukuran besar dengan harga Rp. 17.000" (baliberkarya.com).

Kadis LHK Denpasar, I Ketut Wisada mengaku pihaknya akan terus melakukan evaluasi dan sosialisasi kepada toko modern, supermarket, toko kelontong hingga pasar tradisional di kota Denpasar. Sosialisasi ini juga telah diikuti dengan mengganti tas kantong dengan tas ramah lingkungan. Pihaknya sangat mengapresiasi masyarakat yang sudah mengikuti Perwali ini sebagai upaya bersama untuk mendukung dan mengurangi sampah plastic. Pihaknya akan menindak tegas serta melakukan pemanggilan kepada menejemen toko berjaringan yang masih membandel serta memberikan sanksi administrasi sesuai peraturan yang berlaku.

Sosialiasi

larangan

menggunakan kantong plastik yang masih kurang jelas dibaca oleh masyarakat yang berbelanja ini agar segera dirubah terkait penempatan pada bagian kasir sehingga dapat jelas terbaca dan tersosilisasi dengan baik. Pihaknya juga memanggil manejemen Tiara Dewata dan juga supermarket lainnya untuk terus melakukan sosialiasi dalam pengurangan kantong plastik sesuai Perwali yang telah ditetapkan.

\section{PENUTUP}

Komunikasi sosial tentang kebijakan pembatasan timbulan sampah plastik sekali pakai yang dikeluarkan oleh Gubernur Bali telah berhasil meningkatkan kesadaran masyarakat dalam mengurangi pemakaian plastik dalam kehidupan sehari-hari. Dalam melaksanakan komunikasi sosial,
Gubernur Bali melakukan kontak sosial secara primer (langsung) ataupun sekunder (media massa). Dengan adanya kontak sosial, maka terjadi perubahan sosial sesuai dengan apa yang diharapkan oleh pemerintah provinsi Bali. Adapun perubahan sosial yang telah terjadi antara lain munculnya gerakan Kedas "Sampah Plastik" yang dilakukan oleh seluruh elemen masyarakat Bali. Beberapa diantaranya seperti yang telah dilakukan oleh organisasi pemuda Hindu yaitu Peradah Bali, KMHDI Bali, serta seluruh akademisi dan komponen masyarakat. Pusat perbelanjaan seperti Tiara Dewata, Indomaret, Alfamart juga mendukung Pergub Bali tersebut dengan meniadakan plastik bagi konsumen yang berbelanja. Sebagai gantinya, mereka menyediakan tas belanja ramah lingkungan dengan harga yang bervariasi. Walikota Denpasar juga turut mendukung Pergub Bali tersebut dengan Perwali no 36 tahun 2018 tentang diet plastik. Ditahuntahun mendatang, masyarakat Bali diharapkan semakin mengurangi pemakaian sampah plastik sekali pakai sehingga kesucian, keharmonisan, keselarasan dan keseimbangan lingkungan hidup di Bali bisa terjaga dan Bali bebas sampah tahun 2020 .

\section{DAFTAR PUSTAKA}

Bungin, Burhan. 2006. Sosiologi Komunikasi Teori, Paradigma, dan Diskursus Teknologi Komunikasi di masyarakat. Jakarta: Kencana Prenada Media Group. 
Cangara, Hafied. 2007. Pengantar Ilmu

Komunikasi. Jakarta: PT. Raja Grafindo Persada.

Islamy, M. Irfan. 2009. Prinsip-prinsip

Perumusan Kebijakan Negara.

Jakarta: Bumi Aksara.

Muhadjir, Noeng. 2000. Metode

Penelitian Kualitatif edisi IV. Yogyakarta: Rake Sarasin.

Ramdhani, A., \& Ramdhani, M. A. (2017). Konsep umum pelaksanaan kebijakan publik. Jurnal Publik, 11(01), 1-12.

Tangkilisan, Hesel Nogi. 2003. Implementasi Kebijakan Publik. Yogyakarta: Lukman

Offset YPAPI.

Umar, Husein. 2002. Metode Riset Bisnis. Jakarta: Gramedia Pustaka Utama.

Vera, N., \& Wihardi, D. (2012). "Jagongan" sebagai bentuk komunikasi sosial pada masyarakat Solo dan manfaatnya bagi pembangunan daerah. Jurnal Ilmiah Komunikasi Makna, 2(2), 40-46.

https://www.buletindewata.com/beritadaerah/2019/02/02/10486/bersihbersih-gubernur-koster-ajaksemua-pihak-wujudkan-balibebas-sampah-plastik.html http://bali.tribunnews.com/2018/07/17/ darurat-sampah-plastik-volumerata-rata-timbulan-sampah-dibali-1084910-m3-perhari? page $=$ all

https://www.mongabay.co.id/2018/02/ 15/riset-membuktikan-ini-jenissampah-laut-terbanyak-di-pesisirbali/

https://www.liputan6.com/lifestyle/rea d/3862018/denpasar-bali-mulai- batasi-penggunaan-kantongplastik http://www.balipost.com/news/2019/0 1/08/65498/SegeraDibuat,Perbup-TanganiSampah...html http://metrobali.com/pemkotlaksanakan-gerakan-kedassampah-plastik-di-besakih/ https://beritabali.com/read/2019/01/18/ 201901190004/DipimpinWalikota-Pemkot-DenpasarBagikan-600-Tas-Belanja-di-4Pasar.html https://baliberkarya.com/index.php/rea d/2019/01/02/201901020002/Gel ar-Sidak-Beberapa-TokoMadern-dan-Supermarket-MasihGunakan-Kantong-Plastik.html 